\title{
KARAKTERISTIK PERILAKU PENGGUNA RUANG PUBLIK DI KOTA SEMARANG (STUDI KASUS: TAMAN PROGO, TAMAN INDONESIA KAYA, DAN BKB)
}

\author{
Mila Karmilah ${ }^{1}$ \\ Agus Rochani ${ }^{2}$ \\ Program Studi Perencanaan Wilayah dan Kota Universitas Islam Sultan Agung ${ }^{1,2}$ \\ Penulis Korespondensi e-mail :mila.k@unissula.ac.id
}

\begin{abstract}
The aims of this studi were (i) to describe negative motive of visitors in public space (ii) to explore the public space conditions that endorse the negative behaviour; (iii) the explore the positive behaviour; (iv) to explore positive variables related to public space; and (v) to describes dan mapping behaviour in public space in Semarang City. The methods of this study was mixed methods, combining between qualitative dan quantitative analyze. The number sampel were 243 respondens spreading in 3 public spaces location (Taman Progo, Taman Indonesia Kaya and Banjir Kanal Barat). The result of the research showed that the most user of public space were student and student of universities. The such motives were the public space is free of charge, easy access, nearby and open 24 hours. The variables that influence negative behaviour were the design of public space, lighting, operational timing, and availability of public space officers. The positive benefits of public space were depends on facilities and its design. The Positive public space were for education, socialization, sport activities, recreation and relaxation.

Keywords : characteristic, public space and users
\end{abstract}

\begin{abstract}
ABSTRAK
Tujuan penelitian ini adalah: (i) mendeskripsikan motif berperilaku negatif saat menggunakan ruang publik di Kota Semarang terutama para remaja; (ii) mengeksplorasi variabel kondisi ruang publik yang menjadi pendorong perilaku negatif; (iii) mengeksplorasi variabel kepribadian yang terkait dengan perilaku positif; (iv) mengeksplorasi variabel yang terkait manfaat positif ruang publik di Kota Semarang; dan (v) melakukan penggambaran (descriptif) dan pemetaan (mapping) perilaku pengguna ruang publik di Kota Semarang. Metode penelitian ini adalah mix method, yaitu gabungan antara pendekatan kualitatif dan kuantitatif. Responden dalam penelitian ini sebanyak 243 yang tersebar di 3 (tiga) taman yaitu taman Progo, Taman Indonesia Kaya dan Taman BKB. Hasil Penelitian menunjukkan bahwa Pengguna ruang publik sebagian besar merupakan usia remaja yang berprofesi sebagai mahasiswa/mahasiswi dan pelajar. Hal tersebut dikarenakan ruang publik merupakan tempat yang tanpa biaya (gratis), lokasinya dekat serta akses yang sangat bebas dengan waktu operasional 24 jam. Kondisi ruang publik di Kota Semarang bisa menjadi pendorong perilaku negatif pengguna ruang publik seperti design taman (kerindangan pohon, desain tempat duduk, smoking area, fasilitas persampahan), pencahayaan (kurangnya pencahayaan), waktu operasional, serta aparat dan fasilitas keamanan. Manfaat positif ruang publik yang dapat dirasakan oleh pengguna ruang publik didasari dengan adanya fasilitas-fasilitas di ruang publik itu sendiri maupun design ruang publik. Manfaat positif tersebut diantaranya ruang publik bermanfaat sebagai sarana edukasi dan sosialisasi (berkumpul ataupun mengerjakan tugas kelompok), sarana olahraga, rekreasi maupun relaksasi.

Kata Kunci: karakteristik, ruang publik, pengguna
\end{abstract}


Jurnal Planologi Vol. 17 No. 1, April 2020

Available : http://jurnal.unissula.ac.id/index.php/psa

\section{PENDAHULUAN}

\subsection{Latar Belakang}

Kepadatan penduduk di Kota Semarang yang relatif tinggi, juga diiringi dengan perkembangan jumlah penduduk, dimana menurut data Dinas Kependudukan dan Catatan Sipil, pada 2018 tercatat penduduk Kota Semarang mengalami kenaikan sebesar 1,58 persen dari tahun sebelumnya. Pada bulan Januari 2016 Mei 2016 Pemerintah Kota Semarang juga mencatat sebanyak 11.092 penduduk yang pindah ke Kota Semarang, sebagian besar dari mereka adalah menempuh pendidikan. Hal ini juga menambah besar efek dan impak terhadap berkurangnya ruang untuk relaksasi dan edukasi bagi warga Kota Semarang.

Terkait hal tersebut Pemerintah Kota Semarang sudah menyediakan beberapa ruang publik sebagai salah satu sarana untuk relaksasi dan edukasi bagi warganya. Keberadaan ruang publik, berupa taman dan lain sebagainya, diharapkan dapat dimanfaatkan seoptimal mungkin dengan nilai guna manfaat yang sebesarbesarnya.

Ruang publik yang dimaksud di dalam penelitian ini adalah ruang bersama di Kota Semarang yang mudah diakses setiap saat oleh seluruh masyarakat. Ruang tersebut digunakan untuk aktivitas relaksasi dan edukasi, yaitu sebagai tempat/lokasi untuk bermain, bersantai, berekreasi, dan belajar. Ruang publik yang dimaksud di dalam kajian ini adalah berupa taman kota, pedestrian, dan lain-lain, serta bukan ruang untuk aktivitas belanja, beribadah, dan berolahraga.

Definisi ruang public oleh Carr yang dikutip oleh (Putri dkk, 2010) bahwa ruang public adalah ruang bersama yang mudah diakses setiap saat oleh seluruh masyarakat untuk beraktivitas secara pribadi maupun berkelompok. Lebih lanjut Carr menjelaskan terdapat dua faktor yang harus dipertimbangkan untuk pengoptimalan dalam penggunaan ruang publik yaitu: (1) Use of space, yakni ruang-ruang berbeda yang mampu mewadahi fungsi dan aktivitas yang berbeda pula dan (2) Space for mand context, dapat diartikan sebagai karakter fisik pada ruang tersebut. Batas fisik serta objek menarik yang digunakan sebagai penanda bentuk ruang.

\subsection{Kajian Pustaka}

\section{Definisi Ruang Publik}

Menurut Mulyandari, (2011) menjelaskan bahwa ruang publik adalah suatu wadah 
yang dapat menampung aktivitas atau kegiatan tertentu masyarakat baik secara individu maupun kelompok. Sedangkan menurut Carr (1992), menjabarkan bahwa ruang publik adalah ruang terbuka yang mudah diakses, dimana terdapat orang beraktivitas secara kelompok maupun individu. Dijabarkan juga menurut Darmawan (2005) ruang publik merupakan ruang yang dapat mewadahi kepentingan publik, yang digunakan untuk komunikasi bermain, jaln-jalan serta melepas lelah. Oleh karena itu, di dalam suatu ruang publik harus tersedia fasilitas pendukung beserta fasilitatornya. Fasilitas pendukung ruang publik (Shirvani, 1985) yang dimaksud seperti, sarana prasarana (taman, area parkir, jalan/pedestrian). Sedangkan menurut Hakim (1987) ruang publik sendiri pada dasarnya merupakan wadah untuk menampung segala aktifitas masyarakat baik secara individiu maupun kelompok.

Berdasarkan sifatnya, ruang publik, terbagi menjadi dua yaitu, ruang publik tertutup dan ruang publik terbuka. Dalam hal ini, ruang terbuka merupakan salah satu jenis dari public space (Mulyandari, 2011). Dilihat dari penggunaannya, ruang publik dapat dikategorikan menjadi ruang aktif, ruang setengah aktif dan ruang pasif. Ruang aktif merupakan ruang yang banyak digunakan untuk kegiatan, bisa temporer. Ruang setengah aktif, merupakan ruang yang intensitas penggunaannnya tidak setinggi ruang aktif dan ruang pasif merupakan ruang yang intensitas penggunaannya kurang atau hampir tidak ada.
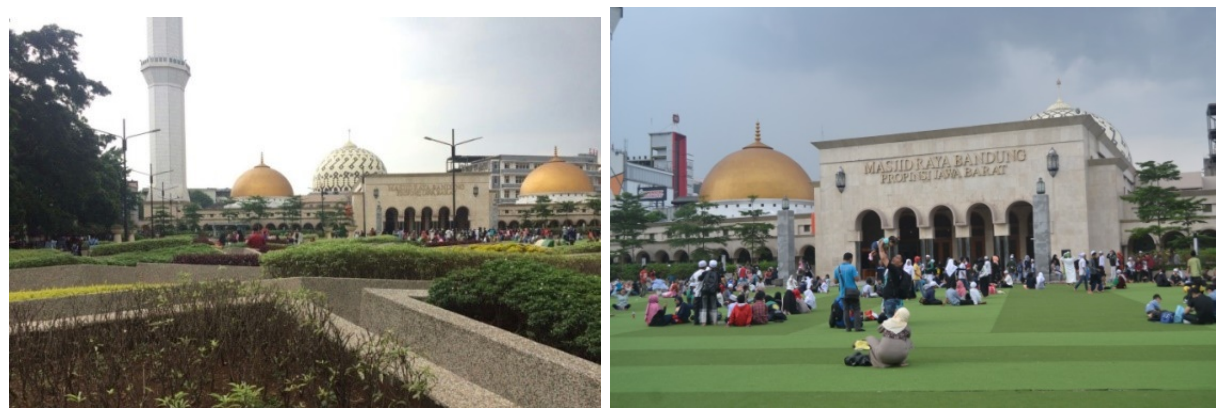

Gambar 1. Contoh Pembagian Ruang pada Ruang Public (open space) di Alun-alun Bandung Sumber : google.com, 2019

Menurut Hatmoko dalam Mulyandari (2011), disebutkan macam-macam public space diantaranya, macam public space berdasarkan bentuknya dibagi atas square dan street. Square adalah cara manusia memanfaatkan ruang urban. Menurut Schulsz dalam Mulyandari, square berkonotasi pada ruang yang bersifat "statis" (dengan artian ruang tersebut terhimpun pada suatu aktivitas tertentu, bersifat memusat serta berorientasi ke 
dalam). Contohnya seperti alun-alun, lapangan bermain, serta taman kota. Street atau jalan merupakan hasil penyebaran permukiman di mana awalnya rumah-rumah tersebut dibangun pada suatu bagian ruang yang mengintari square centralnya. Menurut Schulz dalam Mulyandari, square berkonotasi pada sifat "dinamis" dimana ruang-ruang sirkulasi jalan dan jejalur biasanya bersifat linear, serta berorientasi ke dua ujngnya). Contoh dari square adalah jalan raya, jalur pejalan kaki serta jalan tapak.
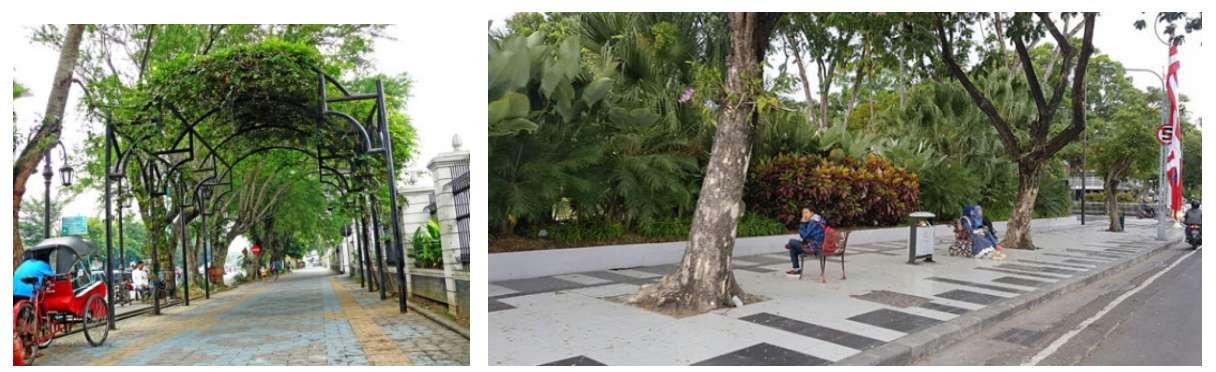

Gambar 2. Contoh Bentuk Publik Space dengan Bentuk Street di (1) Kota Solo; (2) Kota Surabaya Sumber : google.com, 2019

Dalam konteks spasial, ruang publik memiliki pengertian, adalah tempat dimana setiap orang mempunyai hak untuk mengakses tanpa harus membayar. Ruang publik berkaitan dengan semua bagian-bagian dari lingkungan alam, yang meliputi jalan, square, tanah, ruang terbuka hijau dan taman, serta ruang publik atau privat yang dalam aksesnya tidak dibatasi (Carmona et al, 2008).

Berdasarkan uraian diatas, dapat ditarik kesimpulan bahwa ruang publik merupakan suatu ruang yang dapat berfungsi untuk menampung aktivitas masyarakat baik individu maupun berkelompok, dengan tanpa bangunan seperti taman, jalan/koridor.

\section{Peran dan Fungsi Ruang Publik}

Fungsi ruang publik menurut Hendro Prabowo, 2011 diantaranya memberikan rasa nyaman/kenyamanan yang berarti ruang publik seharusnya mampu memberikan fasilitas dengan nyaman. Selanjutnya relaksasi, yang berarti mampu memberikan tempat untuk melepas lelah. Oleh karena itu, ruang publik memiliki peranan dan fungsi ruang publik menurut Carmona, 2008 diantaranya ekonomi, kesehatan, sosial dan lingkungan.

Keberadaan ruang publik merupakan salah satu elemen perancang kota yang berperan penting dalam memenuhi kebutuhan masyarakat sebagai tempat berinteraksi dan bersosial masyarakat. Maka apabila suatu ruang publik dimanfaatkan dengan maksimal, akan memberikan dampak positif yang menguntungkan bagi seluruh penggunanya.

Menurut Rustam Hakim, 2003 menyebutkan bahwa ruang publik memiliki beberapa 
fungsi, diantaranya:

1) Sebagai tempat berkomunikasi dan bersosialisasi

2) Tempat untuk medapatkan udara segar

3) Penghubung antar tempat

4) Sebagai pembatas/ Jarak diantara masa bangunan

5) Sarana untuk menciptakan kebersihan, keserasian dan keindahan lingkungan

Darmawan (2009) menjelaskan bahwa ruang publik, memiliki beberapa fungsi sebagai berikut;

1) Sebagai pusat interaksi

2) Sebagai ruang terbuka yang menampung koridor-koridor

3) Sebagai tempat pedagang kaki lima

4) Sebagai paru-paru kota

Menurut Carr (1992) peran ruang publik yang baik seharusnya mengandung unsur:

1) Kenyamanan, yang meliputi kenyamanan lingkungan kenyamanan fisik, kenyamanan secara sosial dan psikologi

2) Relaksasi, mampu menghadirkan unsur alam seperti terdiri dari tanaman, pohon serta air

3) Aktivitas pasif, seperti aktivitas bersantai untuk menikmati kondisi sekitar/lingkungan

4) Discovery, dilengkapi dengan jalur pedestrian dan fasilitas

Fungsi ruang publik menurut Budiharjo (1998), antara lain:

1. Untuk memenuhi kebutuhan akan tempat rekreasi seperti tempat bermain, berolahraga, bersantai, komunikasi sosial, tempat peralihan serta tempat menunggu

2. Sebagai ruang terbuka/ mendapatkan udara segar dari alam

3. Sarana penghubung antara satu tempat dengan tempat lain

4. Sebagai pembatas atau jarak di antara masa bangunan

\section{METODOLOGI}

Pendekatan penelitian yang digunakan adalah mixed method, yaitu gabungan antara pendekatan kualitatif dan kuantitatif. Dua metode dilakukan secara simultan dan saling bertalian, keduanya memainkan peran secara seimbang dalam analisis dan laporan penelitian.

Metode paling populer yang digunakan dalam mixed methods dengan asumsi kunci dan 
Jurnal Planologi Vol. 17 No. 1, April 2020

Available : http://jurnal.unissula.ac.id/index.php/psa

pandangan bahwa kedua pendekatan (kualitatif dan kuantitatif) akan memberikan informasi yang berbeda digunakan secara bersamaan tidak berurutan. Hal ini didasarkan pada apa yang telah dilakukan oleh Creswell (2014; p-269) bahwa penelitian psikologi akan menghasilkan hasil yang baik jika digunakan dua sumber data. Efektifitas waktu juga menjadi bahan pertimbangan dalam menggunakan metode penelitian ini. Jumlah sampel yang dalam penelitian ini adalah 243 responden dengan metode quota sampling. Sedangkan teknik sampling yang digunakan adalah nonprobability sampling, yaitu Quota Sampling.

\section{HASIL DAN PEMBAHASAN}

\subsection{Karakteristik Taman}

\subsubsection{Taman Progo}

Berlokasi di Jalan Taman Progo, Kelurahan Mlatibaru, Kecamatan Semarang Timur, taman Progo menjadi salah satu alternatif pilihan ruang terbuka yang terletak di tengah-tengah kawasan permukiman padat penduduk. Dengan luas taman sekitar $2000 \mathrm{~m}^{2}$ menjadikan taman Progo sebagai taman permukiman dengan pengunjung yang bervariasi, tidak hanya mereka yang berasal dari kawasan permukiman Progo, namun juga penduduk dari luar kawasan. Dilengkapi dengan berbagai macam permainan anak, sehingga sasaran pengunjung yang datang ke taman Progo tidak hanya dari kalangan orang dewasa, namun

juga anak-anak. Jadwal kunjungan tertinggi taman Progo terjadi pada sore hari, dari pukul 3 sampai 6 sore, dimana aktivitas pengunjung ditemukan cukup variatif, mulai dari aktivitas bermain anak, hingga aktivitas lainnya seperti mengobrol dengan sesama pengunjung taman. Mayoritas pengunjung taman Progo rata-rata berusia 23 tahun. Berikut adalah peta taman Progo. 

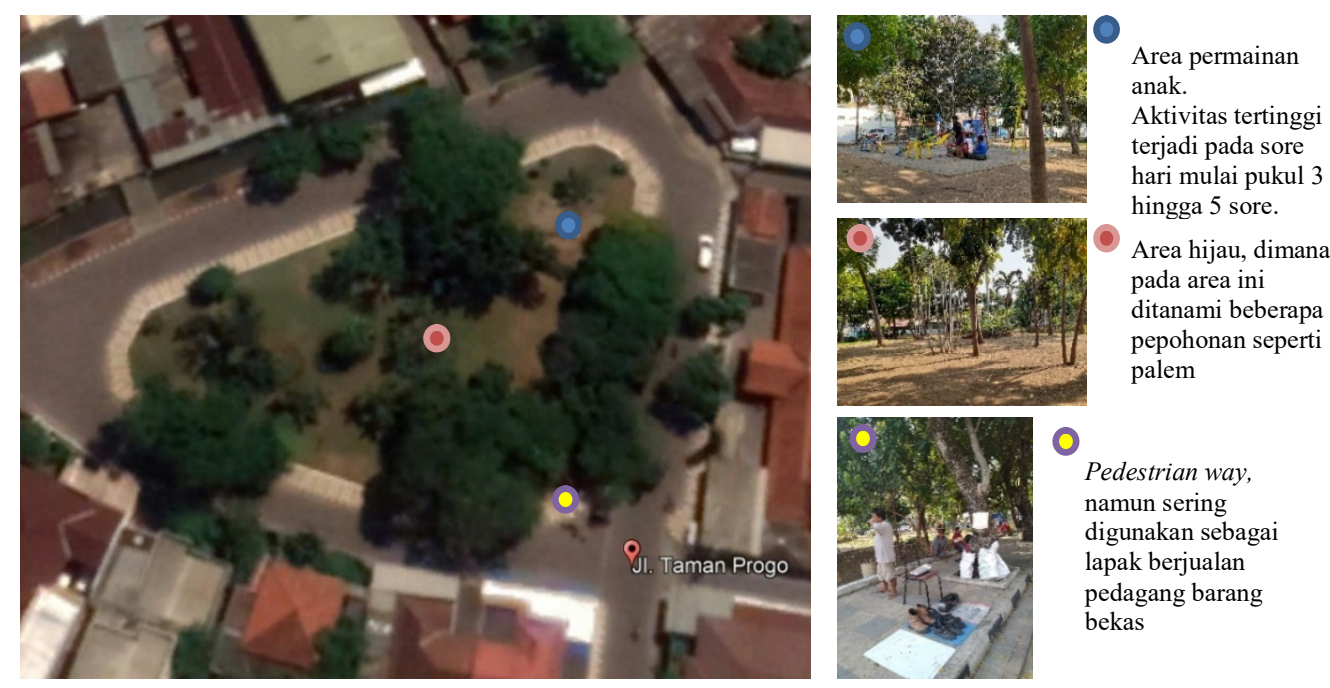

Gambar 3. Lokasi Kegiatan di Taman Progo Sumber: google maps dan deskripsi penulis, 2019

\subsubsection{Taman Indonesia Kaya}

Berlokasi di Jalan Menteri Supeno, Kelurahan Mugassari, Kecamatan Semarang Selatan, taman Indonesia Kaya sebelumnya dikenal dengan taman KB. Kemudian mengalami renovasi dan berganti nama menjadi taman Indonesia Kaya yang diresmikan pada Oktober 2018. Taman Indonesia Kaya memiliki ciri khas berupa panggung yang bisa dimanfaatkan pengunjung untuk melakukan pertunjukkan. Selain itu, terdapat air mancur untuk fungsi estetika, dan beberapa fasilitas lain seperti fasilitas kebersihan berupa tempat sampah dan toilet umum serta penerangan berupa lampu taman. Kunjungan tertinggi terjadi pada sore hari dimana pengunjung banyak melakukan aktivitas olahraga dan rekreasi ataupun relaksasi bagi sebagian pengunjung. Berikut adalah peta taman Indonesia Kaya. 

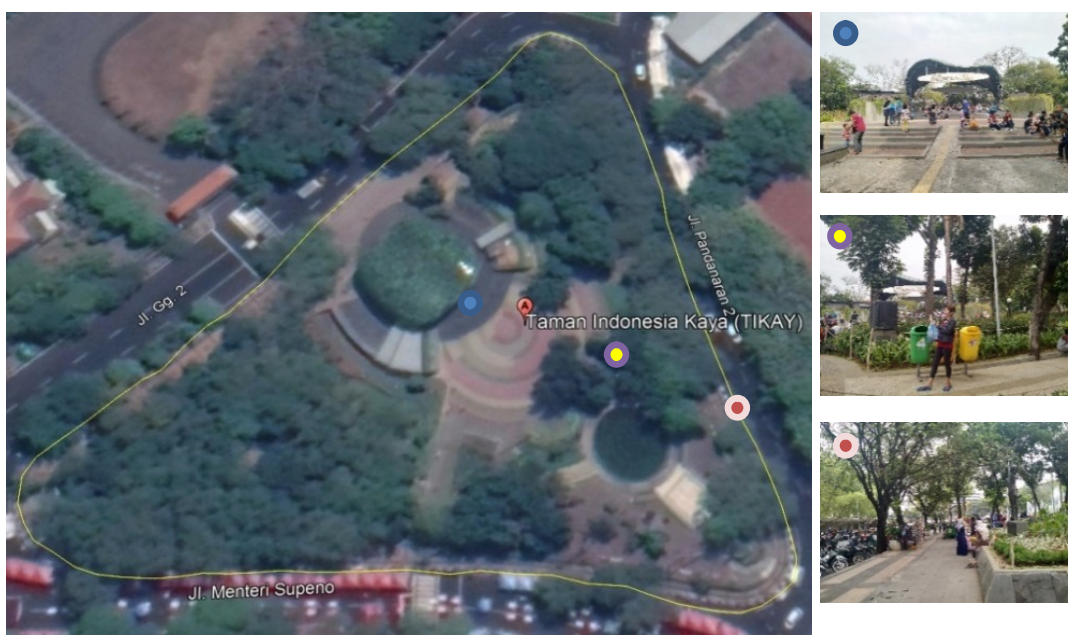

Fasilitas panggung yang bisa difungsikan sebagai sitting group untuk pengunjung

Gambar 4. Fasilitas di Taman Progo Sumber: google maps dan deskripsi penulis, 2019

\subsubsection{Taman Banjir Kanal Barat}

Kawasan Banjir Kanal Barat merupakan salah satu kawasan sempadan sungai yang dijadikan area hijau oleh pemerintah Kota Semarang. Kawasan Banjir Kanal Barat dikenal dengan kawasan yang atraktif dengan permainan air mancur yang biasanya dimainkan ketika event tertentu untuk menarik pengunjung dari kota Semarang maupun luar kota Semarang. Kawasan Banjir Kanal Barat terletak cukup strategis, bersebelahan dengan jalan nasional dimana jalan ini merupakan jalan penghubung antara kota Semarang dengan kabupaten Kendal. Beberapa fasilitas pendukung yang tersedia di kawasan Banjir Kanal Barat antara lain sitting group, jalur untuk pejalan kaki, fasilitas kebersihan seperti tong sampah dan beberapa penerangan berupa lampu taman yang terletak di beberapa sudut kawasan Banjir Kanal Barat. Berikut adalah peta dari kawasan Banjir Kanal Barat. 


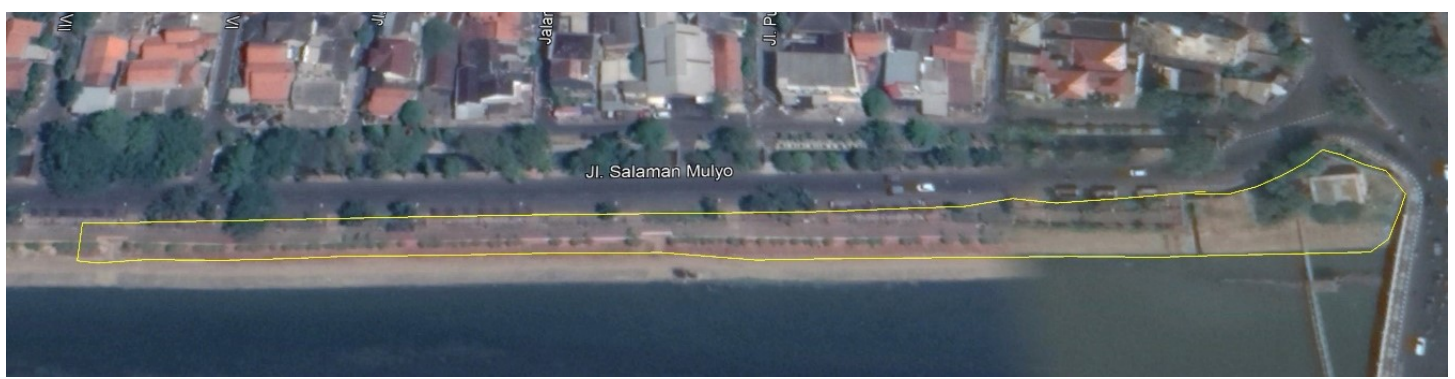

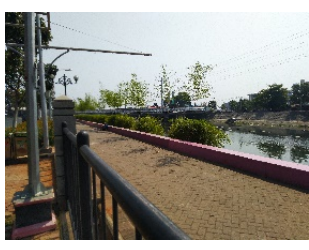

Jalur pejalan kaki yang digunakan pengunjung untuk berjalan-jalan atau olahraga

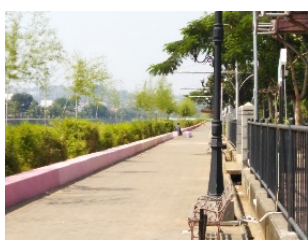

Faslilitas sitting group dan lampu penerangan taman

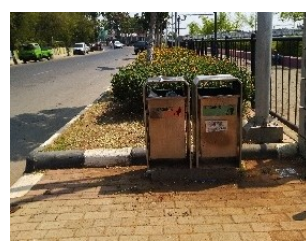

Fasilitas kebersihan yang berupa penyediaan tempat sampah

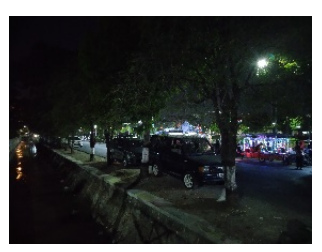

PKL yang tersedia pada malam hari

Gambar 5. Fasilitas di Banjir kanal Barat

Sumber: google maps dan deskripsi penulis, 2019

\subsection{Karakter Pengguna Taman}

\subsubsection{Taman Progo}

Hasil pengujian terhadap taman Progo antara usia dengan lokasi atau spot favorit yang biasa dikunjungi oleh pengunjung di taman Progo, tujuan pengunjung melakukan kunjungan, serta aktivitas negatif yang diidentifikasi oleh pengunjung berdasarkan tanggapan responden adalah sebagai berikut.

Tabel 1. Analisis Deskriptif terhadap Usia, Lokasi Favorit, Tujuan, dan Aktivitas Negatif di Taman

\begin{tabular}{|c|c|c|c|c|c|c|c|c|c|c|c|c|c|}
\hline & & & & & Descri & $\begin{array}{l}\text { rogo } \\
\text { ve Statist }\end{array}$ & & & & & & & \\
\hline & $\mathrm{N}$ & Range & Minimum & Maximum & Sum & & & Std. Deviation & $\begin{array}{l}\text { Variance } \\
\end{array}$ & & & & osis \\
\hline & Statistic & Statistic & Statistic & Statistic & Statistic & Statistic & Std. Error & Statistic & Statistic & Statistic & Std. Error & Statistic & Std. Error \\
\hline USIA & 81 & 34,00 & 14,00 & 48,00 & 1874,00 & 23,1358 & 1,03440 & 9,30961 & 86,669 & .765 & .267 & $-0,652$ & .529 \\
\hline SPOTFAVORIT & 81 & 3,00 & 1,00 & 4,00 & 138,00 & 1,7037 & 11446 & 1,03010 & 1,061 & 1,191 & .267 & ,032 & .529 \\
\hline TUJUAN PENGUNJUNG & 81 & 4,00 & 1,00 & 5,00 & 225,00 & 2,7778 & 12423 & 1,11803 & 1,250 & 289 & .267 &,- 268 & .529 \\
\hline AKTIVITAS NEGATIF & 81 & 7,00 & 1,00 & 8,00 & 145,00 & 1,7901 & .15287 & 1,37583 & 1,893 & 2,013 & ,267 & 4,699 & .529 \\
\hline
\end{tabular}

Sumber: Hasil Analisis, 2019

Rata-rata usia responden adalah 23 tahun dengan usia responden termuda adalah 14 tahun dan usia responden tertua adalah 48 tahun. Untuk lokasi favorit pengunjung, rata-rata responden memilih opsi 1 dan 2, dimana area ini adalah area permainan anak dan dan area kuliner.

Tujuan pengunjung, untuk berwisata keluarga dan bertemu orang lain (menjadikan ruang terbuka sebagai meeting point) serta resting point (area untuk beristirahat atau singgah sebelum melakukan perjalanan kembali, didukung dengan beberapa fasilitas taman 
seperti area bermain anak sehingga banyak pengunjung yang datang dengan anak-anaknya. Aktivitas negatif yang dilakukan pengunjung yakni membuang sampah sembarangan serta parkir yang kurang beraturan dikarenakan pada tidak terdapat area parkir. Berdasarkan tabel, diketahui bahwa pengunjung terbanyak berasal dari kalangan remaja, yakni berumur 15-19 tahun dengan jumlah responden sebanyak 45 orang (56\%). Kemudian pengunjung berusia 30-34 tahun dengan 15 responden (19\%), 25-29 tahun dengan 8 responden (10\%) 35-49 tahun dengan total 5 responden (6\%), 40-45 tahun dengan responden sebanyak 4 orang (5\%), dan pengunjung dengan responden paling sedikit yakni berasal darii usia 4549 tahun dengan 1 responden (1\%).

Keberadaan pengunjung dengan usia remaja terbanyak disebabkan oleh lokasi taman yang berdekatan dengan sekolah. Selain itu, didukung dengan data Semarang Timur Dalam Angka 2019, penduduk usia 15-19 tahun menempati posisi ke 2 penduduk dengan rentang usia terbanyak dengan jumlah 729 jiwa. Pengunjung dengan rentang usia 15-19 tahun juga mempengaruhi jenis aktivitas yang terdapat di taman Progo. Seperti terlihat pada grafik 1 dibawah

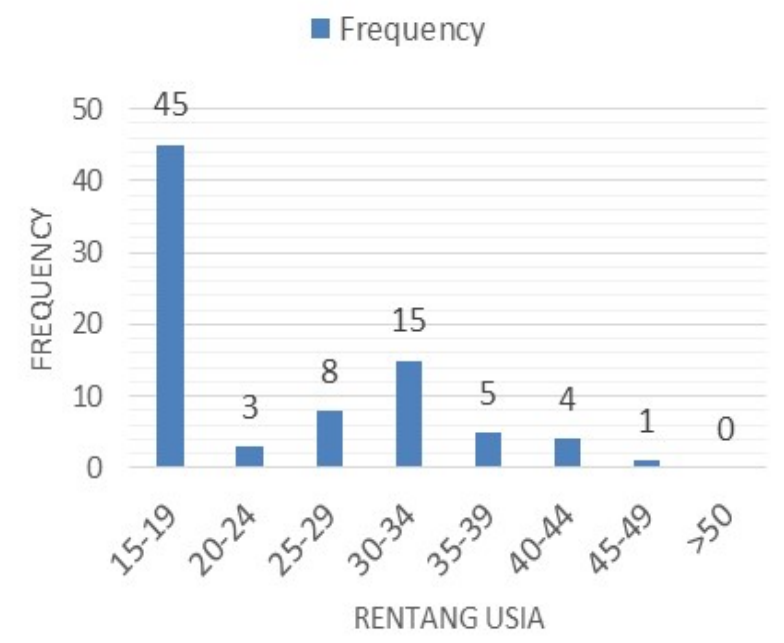

Gambar 6. Rentang Usia Pengunjung Taman Progo Sumber: Hasil Analisis, 2019

\section{- Lokasi Favorit Pengunjung}

Masing-masing pengunjung memiliki lokasi favoritnya, mulai dari area permainan anak, area olahraga, area kuliner, area sitting group, bahkan blind spot atau area tidak terlihat. Adapun hasil respons yang telah terekam terhadap kunjungan di taman Progo adalah sebagai berikut. 
Tabel 2. Lokasi Favorit Pengunjung Taman Progo

\begin{tabular}{|c|l|c|c|}
\hline No. & \multicolumn{1}{|c|}{ Area } & Frekuensi & Persentase \\
\hline 1 & Permainan Anak & 50 & $62 \%$ \\
\hline 2 & Kuliner & 13 & $16 \%$ \\
\hline 3 & Sitting Group & 10 & $12 \%$ \\
\hline 4 & Olahraga & 8 & $10 \%$ \\
\hline \multicolumn{2}{|c|}{ TOTAL RESPONS } & 81 & $100 \%$ \\
\hline
\end{tabular}

Sumber: Hasil Analisis, 2019

Dari tabel tersebut, pengunjung paling sering melakukan kunjungan ke area permainan anak dengan jumlah respons sebnayak 50 responden (62\%), disusul dengan area kuliner yang dipilih 13 responden (16\%), area sitting group dengan 10 responden (12\%) dan area olahraga sebanyak 8 responden (10\%). Ketiadaan pengunjung yang memilih blind spot pada taman Progo dikarenakan area taman seluruhnya tercover, dan jam kunjungan yang dilakukan pengujung yang rata-rata jam 2 siang hingga jam 6 sore. Area permainan anak memiliki jumlah responden terbanyak dikarenakan area ini menjadi highlight dari taman Progo. Selain itu, beberapa spot digunakan untuk berjualan barang-barang bekas sehingga pengunjung lebih memusatkan kegiatan di area permainan anak yang tidak berdekatan dengan tempat berjualan.

\section{- Tujuan Pengunjung Melakukan Kunjungan}

Masing-masing pengunjung memiliki tujuan ketika melakukan kunjungan ke kawasan taman Progo yang kemudian terbagi menjadi 5 jenis tujuan antara lain sebagai meeting point ataupun resting point dengan jumlah responden terbanyak yakni 34 responden (42\%), disusul dengan berwisata keluarga dengan jumlah responden sebanyak 20 responden $(25 \%)$, berwisata kuliner sebanyak 11 responden $(14 \%)$, dan olahraga serta mengobrol dengan masing-masing responden sebanyak 8 responden (10\%). Taman Progo menjadi meeting point ataupun resting point ketika melakukan perjalanan dikarenakan letak taman yang strategis dan mudah untuk dijangkau oleh pengunjung taman Progo. Kebanyakan pengunjung berusia 15-19 tahun menjadikan taman Progo sebagai meeting point dikarenakan letaknya yang berdekatan dengan sekolah sehingga mudah untuk diidentifikasi. Pengunjung dengan tujuan wisata keluarga menempati posisi kedua dikarenakan highlight dari taman Progo adalah area bermain anak dan jadwal kunjungan tertinggi terjadi pada sore hari mulai pukul 4 sore hingga 6 sore dimana anak-anak banyak bermain di area taman Progo dan banyak orang tua yang mengawasi anaknya bermain di area taman. 
Tabel 3. Tujuan Pengunjung Taman Progo

\begin{tabular}{|c|l|c|c|}
\hline No. & Tujuan Pengunjung & Frekuensi & Persentase \\
\hline 1 & Wisata kuliner & 11 & $14 \%$ \\
\hline 2 & Wisata keluarga & 20 & $25 \%$ \\
\hline 3 & Meeting point & 34 & $42 \%$ \\
\hline 4 & Olahraga & 8 & $10 \%$ \\
\hline 5 & Mengobrol & 8 & $10 \%$ \\
\hline \multicolumn{2}{|c|}{ TOTAL RESPONS } & 81 & $100 \%$ \\
\hline
\end{tabular}

Sumber: Hasil Analisis, 2019.

\subsubsection{Taman Banjir Kanal Barat}

Hasil pengujian terhadap kawasan Banjir Kanal Barat (BKB) antara usia dengan lokasi atau spot favorit yang biasa dikunjungi oleh pengunjung di kawasan BKB, tujuan pengunjung melakukan kunjungan, serta aktivitas negatif yang diidentifikasi oleh pengunjung berdasarkan tanggapan responden adalah sebagai berikut.

Tabel 4. Analisis Deskriptif Terhadap Usia, Lokasi Favorit, Tujuan, dan Aktivitas Negatif di Kawasan Banjir Kanal Barat (BKB)

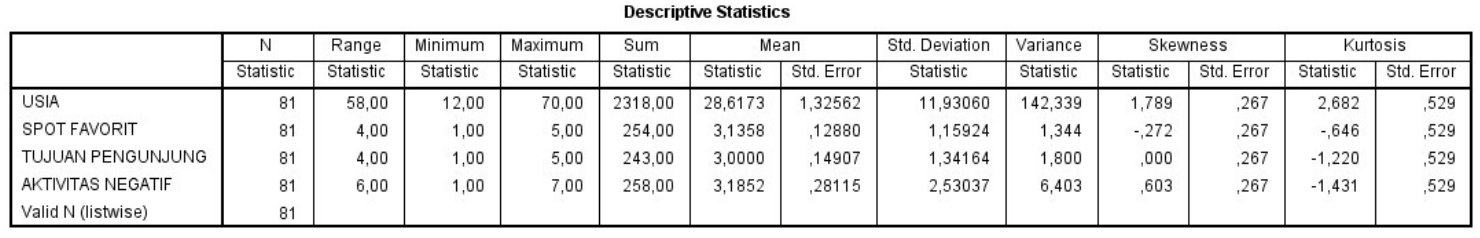

Sumber: Hasil Analisis, 2019

Diketahui bahwa usia pengunjung termuda adalah 12 tahun dengan usia tertua adalah 70 tahun. Rata-rata pengunjung yang datang ke kawasan Banjir Kanal Barat adalah mereka yang berusia 28-29 tahun.

Pada variabel spot favorit pengunjung, rata-rata pengunjung memilih opsi 3 yang merupakan area sitting group dikarenakan letak kawasan Banjir Kanal Barat yang cukup strategis, dan sangat mudah diakses serta diidentifikasi sehingga banyak pengunjung yang menjadikan kawasan Banjir Kanal Barat sebagai meeting point ataupun resting point untuk beristirahat dan kembali melakukan perjalanan. Area sitting group pada kawasan Banjir Kanal Barat ditempatkan dengan pola memanjang mengikuti alur sungai Banjir Kanal Barat dengan penambahan ornamen lampu taman di setiap sudutnya

Pada variabel bentuk kegiatan negatif pengunjung, rata-rata pengunjung memilih opsi 3 dan 4 sebagai bentuk aktivitas negatif yang sering dilihat pengunjung yakni merokok di area taman dan merusak fasilitas. Kurangnya kesadaran pengunjung terhadap menjaga kebersihan dan menjaga fasilitas taman nampaknya masih kurang sehingga beberapa fasilitas taman menjadi rusak, seperti mencoret-coret bangku taman adalah salah satu kegiatan merusak fasilitas taman dan perlu adanya regulasi mengenai hal ini. 
Jurnal Planologi Vol. 17 No. 1, April 2020

\section{- Usia}

Dari hasil penyebaran kuesioner yang telah dilakukan, maka didapatkan hasil sebagai berikut. Diketahui bahwa pengunjung terbanyak berusia 21-28 tahun dengan jumlah responden sebanyak 52 orang atau 64\%. Kemudian disusul oleh pengunjung berusia 29-36 tahun dengan 8 responden (10\%), 12-20 tahun serta 45-52 tahun dengan masing-masing 6 responden (7\%), usia 37-44 tahun dan 53-60 tahun dengan masing-masing 3 responden (4\%), sedangkan yang berusia lebih dari 68 tahun dengan jumlah responden 2 orang (2\%) dan usia dengan responden paling sedikit yakni 61-68 tahun dengan total responden 1 orang $(1 \%)$.

Keberadaan pengunjung dengan rentang usia 21-28 tahun menjadikan kawasan Banjir Kanal Barat sebagai kawasan yang diminati untuk duduk dan mengobrol ataupun berolahraga di sekitar kawasan banjir kanal barat dengan memanfaatkan jalur pejalan kaki yang terdapat pada kawasan BKB.

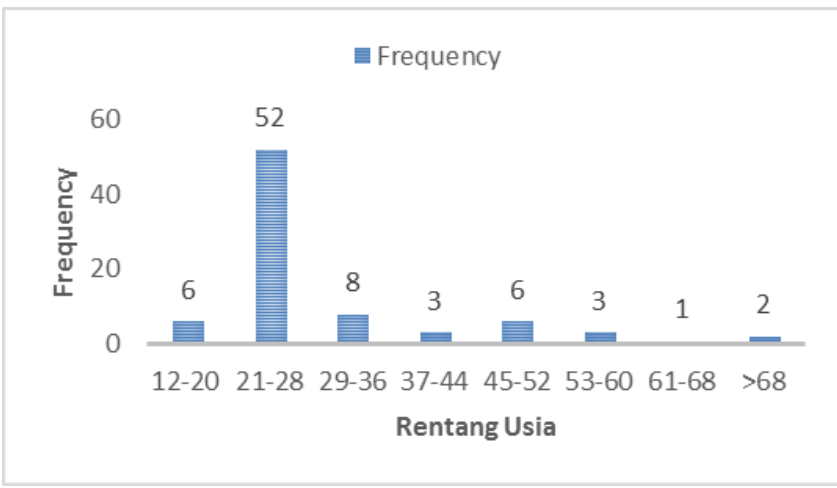

Gambar 7. Rentang Usia Pengunjung Kawasan BKB

Sumber: Hasil Analisis, 2019

\section{- Lokasi Favorit Pengunjung}

Masing-masing pengunjung memiliki lokasi favoritnya, mulai dari area permainan anak, area olahraga, area kuliner, area sitting group, bahkan blind spot atau area tidak terlihat. Adapun hasil respons yang telah terekam terhadap kunjungan di kawasan BKB adalah sebagai berikut.

Tabel 5. Lokasi Favorit Pengunjung Kawasan BKB

\begin{tabular}{|c|l|c|c|}
\hline No. & \multicolumn{1}{|c|}{ Area } & Frekuensi & Persentase \\
\hline 1 & Permainan Anak & 9 & $11 \%$ \\
\hline 2 & Kuliner & 13 & $16 \%$ \\
\hline 3 & Sitting Group & 26 & $32 \%$ \\
\hline 4 & Olahraga & 24 & $30 \%$ \\
\hline 5 & Blind Spot & 9 & $11 \%$ \\
\hline \multicolumn{2}{|c|}{ TOTAL RESPONS } & 81 & $100 \%$ \\
\hline
\end{tabular}

Sumber: Hasil Analisis, 2019 
Dari tabel tersebut, pengunjung paling banyak mengujungi ke area sitting group dengan jumlah responden sebanyak 26 orang (32\%), disusul dengan area olahraga dengan total responden sebanyak 24 orang (30\%), area kuliner dengan jumlah responden yang memilih opsi ini adalah 13 orang (16\%), serta area permainan anak dan blind spot dengan masing-masing mendapatkan 9 orang responden (11\%). Pengunjung memilih sitting group area karena posisinya yang langsung menghadap sungai Banjir Kanal Barat sehingga pengunjung bisa juga melakukan kegiatan relaksasi.

\section{- Tujuan Pengunjung Melakukan Kunjungan}

Masing-masing pengunjung memiliki tujuan melakukan kunjungan ke kawasan BKB adalah untuk berolahraga dan wisata keluarga sebagai tujuan pengunjung melakukan kunjungan ke kawasan BKB dengan jumlah responden sebanyak 20 responden (25\%), disusul dengan bertemu dengan orang ataupun area beristirahat dengan jumlah responden sebanyak 15 orang (19\%), serta mengobrol dengan sesama pengunjung dan wisata kuliner dengan masing-masing responden yang memilih opsi ini adalah 13 responden (16\%). Banyaknya pengunjung yang memiliki tujuan olahraga dan wisata keluarga ke kawasan BKB dikarenakan kawasan ini menyediakan area olahraga yang bisa digunakan oleh seluruh lapisan umur dan seluruh kalangan. Pengunjung bisa melakukan aktivitas olahraga seperti bersepeda ataupun jogging di bantaran sungai Banjir Kanal Barat. yang kemudian terbagi menjadi 5 jenis tujuan pengunjung antara lain berwisata keluarga dengan memanfaatkan sarana prasarana yang tersedia di kawasan BKB, berwisata kuliner, menjadikan kawasan BKB sebagai resting point ataupun meeting point ketika melakukan perjalanan, berolahraga, serta mengobrol dengan sesama pengguna taman yang lainnya. Berikut adalah hasil distribusi frekuensi terhadap tujuan pengunjung saat melakukan kunjungan ke kawasan BKB.

Tabel 6. Tujuan Pengunjung Kawasan BKB

\begin{tabular}{|c|l|c|c|}
\hline No. & Tujuan Pengunjung & Frekuensi & Persentase \\
\hline 1 & Wisata kuliner & 13 & $16 \%$ \\
\hline 2 & Wisata keluarga & 20 & $25 \%$ \\
\hline 3 & Meeting point & 15 & $19 \%$ \\
\hline 4 & Olahraga & 20 & $25 \%$ \\
\hline 5 & Mengobrol & 13 & $16 \%$ \\
\hline \multicolumn{2}{|c|}{ TOTAL RESPONS } & 81 & $100 \%$ \\
\hline
\end{tabular}

Sumber: Hasil Analisis, 2019 


\section{- Bentuk Aktivitas Negatif yang Ditemukan Pengunjung}

Identifikasi dari bentuk aktivitas negatif pengunjung berasal dari respons pengunjung terhadap apa yang dilihat dan dirasakan pengunjung setiap melakukan kunjungan ke kawasan BKB yang kemudian teridentifikasi menjadi 8 jenis yakni membuang sampah tidak pada tempatnya, parkir kendaraan yang tidak rapi, merokok di taman, merusak fasilitas taman, berpacaran di taman, PKL dan pengamen yang mengganggu, fasilitas taman yang tidak dirawat, serta pengunjung yang tidak menemukan adanya bentuk aktivitas negatif di taman.

Tabel 7. Bentuk Aktivitas Negatif Kawasan BKB

\begin{tabular}{|c|l|c|c|}
\hline Kode & \multicolumn{1}{|c|}{ Bentuk Aktivitas } & Frekuensi & Persentase \\
\hline 1 & $\begin{array}{l}\text { Membuang sampah } \\
\text { sembarangan }\end{array}$ & 36 & $44 \%$ \\
\hline 2 & Parkir kendaraan tidak rapi & 13 & $16 \%$ \\
\hline 3 & Merokok & 1 & $1 \%$ \\
\hline 4 & Merusak fasilitas taman & 3 & $4 \%$ \\
\hline 5 & Berpacaran di taman & 6 & $7 \%$ \\
\hline 6 & PKL dan pengamen & 3 & $4 \%$ \\
\hline 7 & Fasilitas yang tidak dirawat & 19 & $23 \%$ \\
\hline \multicolumn{2}{|l|}{ TOTAL RESPONS } & 81 & $100 \%$ \\
\hline
\end{tabular}

Sumber: Hasil Analisis, 2019

Bentuk aktivitas negatif terbanyak yang adalah membuang sampah sembarangan dengan total pengunjung yang memilih opsi ini adalah 36 responden dengan persentase $44 \%$, disusul oleh fasilitas yang tidak terawat dengan total responden yang memilih opsi ini sebanyak 19 responden (23\%), kemudian parkir kendaraan yang tidak rapi dengan total 13 responden (16\%), pengunjung yang merusak fasilitas taman dan PKL dan pengamen dengan masing-masing mendapatkan 3 responden yang memilih opsi ini dengan persentase $4 \%$ dan merokok di posisi terakhir dengan total responden yang memilih opsi ini sebanyak 1 orang (1\%). Masih banyaknya pengunjung yang membuang sampah sembarangan mengindikasikan bahwa pengunjung masih kurang kesadarannya akan kebersihan lingkungan. Selain itu, pengunjung yang merusak fasilitas yang disediakan pihak pengelola baik dengan cara mencoret-coret ataupun jenis lainnya juga termasuk tindakan melanggar hukum dan seharusnya ada sangsi tegas terkait hal ini karena merusak fasilitas dapat mengganggu kenyamanan pengunjung yang lainnya. 
Jurnal Planologi Vol. 17 No. 1, April 2020

Available : http://jurnal.unissula.ac.id/index.php/psa

\section{KESIMPULAN DAN SARAN}

\subsection{Kesimpulan}

\begin{tabular}{|c|c|c|c|c|}
\hline \multirow{2}{*}{ No } & \multirow{2}{*}{$\begin{array}{l}\text { Variabel Ruang } \\
\text { Terbuka Publik }\end{array}$} & \multicolumn{3}{|c|}{ Ruang Terbuka Publik } \\
\hline & & Kawasan BKB & Taman Progo & Taman Indonesia Kaya \\
\hline \multirow[t]{7}{*}{1} & \multicolumn{4}{|c|}{ Kondisi Ruang Terbuka Publik } \\
\hline & Desain tanaman & $\begin{array}{l}\text { Tanaman didominasi } \\
\text { tanaman perdu } \\
\text { disepanjang trotoar }\end{array}$ & $\begin{array}{l}\text { Terdiri dari jenis tanaman } \\
\text { perdu yang mengcover } \\
\text { seluruh area taman dan } \\
\text { tanaman bonsai hias untuk } \\
\text { menambah kesan estetik } \\
\text { kawasan }\end{array}$ & $\begin{array}{l}\text { Tanaman perdu } \\
\text { diletakkan di sekitaran } \\
\text { area pedestrian serta } \\
\text { terdapat tanaman hias } \\
\text { untuk menambah estetika } \\
\text { kawasan }\end{array}$ \\
\hline & Kebersihan & Cukup bersih & Cukup bersih & Cukup bersih \\
\hline & Pencahayaan & $\begin{array}{l}\text { Kurang mengcover } \\
\text { seluruh kawasan }\end{array}$ & $\begin{array}{l}\text { Beberapa titik tidak } \\
\text { mendapatkan pencahayaan } \\
\text { karena terhalang pohon }\end{array}$ & $\begin{array}{l}\text { Beberapa titik tidak } \\
\text { tercover karena terhalang } \\
\text { pohon }\end{array}$ \\
\hline & $\begin{array}{l}\text { Waktu } \\
\text { operasional }\end{array}$ & $24 \mathrm{jam}$ & 24 jam & 24 jam \\
\hline & Keamanan & $\begin{array}{l}\text { Tidak ditemukan } \\
\text { adanya petugas } \\
\text { keamanan ataupun } \\
\text { petugas parkir }\end{array}$ & $\begin{array}{l}\text { Adanya petugas parkir yang } \\
\text { mulai berjaga mulai sore } \\
\text { hingga pukul } 11 \text { malam }\end{array}$ & $\begin{array}{l}\text { Adanya petugas parkir } \\
\text { yang berjaga di sekitar } \\
\text { kawasan PKL taman } \\
\text { Indonesia Kaya }\end{array}$ \\
\hline & $\begin{array}{l}\text { Kondisi malam } \\
\text { hari }\end{array}$ & $\begin{array}{l}\text { Tidak terlalu ramai } \\
\text { dan tidak terlalu sepi. } \\
\text { Hanya pada event } \\
\text { tertentu akan ramai }\end{array}$ & Sepi pengunjung & $\begin{array}{l}\text { Ramai pengunjung } \\
\text { terutama mahasiswa. } \\
\text { Sering digunakan untuk } \\
\text { tempat berkumpul } \\
\text { komunitas }\end{array}$ \\
\hline 2 & \multicolumn{4}{|c|}{ Kepribadian Pengguna Ruang Terbuka Publik } \\
\hline & Profil pengunjung & $\begin{array}{l}\text { Pengunjung } \\
\text { didominasi mahasiswa } \\
\text { berusia } 20 \text { tahunan }\end{array}$ & $\begin{array}{l}\text { Pengunjung didominasi } \\
\text { laki-laki berusia } 20-40 \\
\text { tahun dengan mata } \\
\text { pencaharian karyawan }\end{array}$ & $\begin{array}{l}\text { Pengunjung didominasi } \\
\text { pelajar dan mahasiswa } \\
\text { berusia belasan hingga } 20 \\
\text { tahunan. }\end{array}$ \\
\hline & $\begin{array}{l}\text { Interaksi antar } \\
\text { individu }\end{array}$ & $\begin{array}{l}\text { Jarang terjadi interaksi } \\
\text { antar pengunjung }\end{array}$ & $\begin{array}{l}\text { Interaksi terjadi antar } \\
\text { pengunjung yang memiliki } \\
\text { relasi }\end{array}$ & $\begin{array}{l}\text { Interaksi pengunjung } \\
\text { terjadi antara pengunjung } \\
\text { yang membawa relasi ke } \\
\text { taman }\end{array}$ \\
\hline & Etika pergaulan & $\begin{array}{l}\text { Mematuhi norma } \\
\text { sosial dan etika } \\
\text { pergaulan, namun } \\
\text { orang yang berpacaran } \\
\text { kurang mengindahkan } \\
\text { norma sosial dan etika } \\
\text { pergaulan }\end{array}$ & $\begin{array}{l}\text { Tidak ditemukan etika } \\
\text { pergaulan yang menjurus ke } \\
\text { arah negatif }\end{array}$ & $\begin{array}{l}\text { Orang-orang yang } \\
\text { pacaran kurang } \\
\text { memperhatikan norma } \\
\text { dan etika pergaulan }\end{array}$ \\
\hline & $\begin{array}{l}\text { Pengunjung } \\
\text { malam hari }\end{array}$ & $\begin{array}{l}\text { Didominasi oleh } \\
\text { mahasiswa dan anak } \\
\text { muda }\end{array}$ & Sepi & $\begin{array}{l}\text { Didominasi anak muda } \\
\text { dan mahasiwa }\end{array}$ \\
\hline 3 & \multicolumn{4}{|c|}{ Manfaat Positif Ruang Terbuka Publik } \\
\hline & Unsur edukasi & Tidak ditemukan & $\begin{array}{l}\text { Adanya pedagang yang } \\
\text { menjajakan dagangan } \\
\text { gambar untuk diwarnai atau } \\
\text { melukis }\end{array}$ & $\begin{array}{l}\text { Ketika Minggu pagi } \\
\text { sering ada senam bersama }\end{array}$ \\
\hline & Unsur hiburan & $\begin{array}{l}\text { Hanya ketika event } \\
\text { atau perayaan tertentu }\end{array}$ & $\begin{array}{l}\text { Adanya grup musik yang } \\
\text { bermain pada malam }\end{array}$ & $\begin{array}{l}\text { Ketika ada pagelaran di } \\
\text { taman }\end{array}$ \\
\hline
\end{tabular}


Jurnal Planologi Vol. 17 No. 1, April 2020

Available : http://jurnal.unissula.ac.id/index.php/psa

\begin{tabular}{|l|l|l|l|l|}
\hline & & tertentu & \\
\hline & Unsur relaksasi & $\begin{array}{l}\text { Cukup baik untuk } \\
\text { dijadikan area } \\
\text { relaksasi karena cukup } \\
\text { tenang }\end{array}$ & $\begin{array}{l}\text { Cukup baik untuk dijadikan } \\
\text { area relaksasi terutama } \\
\text { siang hari }\end{array}$ & $\begin{array}{l}\text { Cukup baik untuk } \\
\text { dijadikan area relaksasi } \\
\text { terutama pada bagian } \\
\text { pedestrian }\end{array}$ \\
\hline
\end{tabular}

\subsection{Saran}

Perlu adanya controlling pada tiap ruang terbuka publik, dikarenakan masih adanya pengunjung yang melakukan kegiatan merusak fasilitas publik. Promosi terhadap beberapa ruang terbuka publik yang menjadi ikon juga lebih ditingkatkan sehingga masyarakat tidak hanya mengenal 1 atau 2 ruang publik di Kota Semarang. Bagi taman-taman yang kurang pencahayaan perlu menambah pencahayaan terutama pada malam hari, serta pada lokasi yang terlalu teduh juga perlu dilakukan pengawasan.

Masyarakat lebih aktif lagi dalam berpartisipasi untuk meramaikan ruang terbuka publik. Juga dituntut kesadarannya akan kebersihan lingkungan dengan cara membuang sampah pada tempatnya.

\section{DAFTAR PUSTAKA}

Allport, Gordon W. (1951). The Individual and his Religion: a Psychological Interpretative. New York: The Macmillan Company.

Amos, C., Holmes, G. \& Strutton, D., (2008). Explorig the relationship between celebrity endorser effect and advertising effectivenesss. A quantitative synthesis of effect size. International Journl of Advertising. 27(2), 209-234

Budihardjo, Eko. (1998). Arsitektur dan Kota di Indonesia. Bandung: PT. Alumni.

Carmona, Matthew et. al. 2008. Public Place Urban Space: The Dimention of Urban Design. New York: Elsevier.

Carr, Stephen, dkk. (1992). Public Space. Combridge University Press. USA.

Creswell, J.W. 2014. Research Design Qualitative, Quanitative, and Mix Methods Approaches $4^{\text {th }}$ ed. SAGE Publications, Inc

Darmawan, Edy. (2005). Analisa Ruang Publik. Kota Semarang: Universitas Diponegoro.

Darmawan, E. (2009) Ruang Publik dalam Arsitektur Kota. Semarang: Badan Penerbit UNDIP.

Hakim, Rustam. (1987). Unsur Perancangan Dalam Arsitektur Lansekap. Jakarta.

Hakim, Rustam. (2003). Komponen Perancangan Arsitektur Lansekap. Jakarta: Penerbit Bumi Aksara 
Jurnal Planologi Vol. 17 No. 1, April 2020

Available : http://jurnal.unissula.ac.id/index.php/psa

Hendro Prabowo, dkk. (2011). Ruang Publik di Jalan Raya Bogor dan Sekitarnya. Proceeding PESAT . Vol 4 Okt 2011, Jakarta Univ Guna Darma

Holland, John L. (1985). Making Choice: A Theory of Vocational Personalities and Work Enviroments. Prentice Hall, Inc. Enslewood Cliff, New Jersey

Johnson, R.A. and Wichern, D. W. 2007. Applied Multivariate Statistical Analysis. sixth edition, Pearson Education Inc: USA,

Mulyandari, Hestin. (2011). Pengantar Perancangan Kota. Yogykarta: Penerbit Andi

Putri dkk (2010)., Analisis Spasial dan Temporal Perubahan Luas Ruang Terbuka Hijau di Bandung, Jurnal Lanskap Indonesia 2 (2), 115-121

Shirvani, Hamid. (1985). The Urban Design Process. New York: Van Nostrand Reinhold Company. 